University for Business and Technology in Kosovo

UBT Knowledge Center

Nov 7th, 9:00 AM - 5:00 PM

\title{
A theoretical perspective on approaches used to define indicators that measure health quality services
}

Rezarta Kalaja

University of Durres, rezartak@hotmail.com

Follow this and additional works at: https://knowledgecenter.ubt-uni.net/conference

Part of the Business Commons

\section{Recommended Citation}

Kalaja, Rezarta, "A theoretical perspective on approaches used to define indicators that measure health quality services" (2015). UBT International Conference. 36.

https://knowledgecenter.ubt-uni.net/conference/2015/all-events/36

This Event is brought to you for free and open access by the Publication and Journals at UBT Knowledge Center. It has been accepted for inclusion in UBT International Conference by an authorized administrator of UBT Knowledge Center. For more information, please contact knowledge.center@ubt-uni.net. 


\title{
A theoretical perspective on approaches used to define indicators that measure health quality services
}

\author{
Rezarta Kalaja \\ Faculty of Professional Studies, University of Durres, Albania \\ rezartak@hotmail.com
}

\begin{abstract}
Increased demands on life quality in its every aspect, has impose certain obligations on evaluating health services quality, which has become one of the key prerequisites, not only for health care organizations, but also for governments and society. Quality, serves as an essential factor in defining and evaluating a health care institution, as well as, an indispensable competing tool between private and public sector, offering these kind of services. Consequently given the importance of the argument, numerous studies and analyses, has been carried out through years by various researchers and organizations all over the world, to identify the key indicators used to assess hospital services quality, and to find the most appropriate method to choose them. Therefore this article aims to describe different methods and efforts, made, to evaluate indicators used to measure health service quality, to better understand their point of view, their implications and applications, in order to select and propose most feasible methods, to use in Albanian context.
\end{abstract}

Keywords: Indicators, Health care, Service Quality, Assessment

\section{Introduction}

When most people are asked to define quality during their time of illness aside error intolerance would probably answered to obtain the best care possible including respectful consideration and care by medical professionals, patience and clear answers to their questions. These "quality indicators" have been opted as high quality measurements of medical care of a critical importance for the well- being of patients as well as for the overall society and economy and are gaining importance in many EU Member States. However, there are still many challenges facing those involved in indicator development. By analyzing and reporting on a common set of measures, health specialists and institutions can compare data and their decision can be well grounded. That is why the article offers an inclusive theoretical review and conceptual framework of indicators and respective dimensions used to measure health quality services globally. Albanian experience dictated by EU policies and latest development is also given in followed by relevant conclusions and recommendations.

\section{Quality of health care: Definitions and importance}

The literature on health quality systems is very extensive and at the same time difficult to systematize. Depending on the disciplinary prototype, quality can be understood in diverse ways by using different terms, labels and models. Where there seems to be agreement is that there is no consensus on how to define quality of care and that the lack of a common systematic framework is, to a considerable extent, due to the diversity in the language used to describe this concept (Legido-Quigley et.al, 2008). Consequently, different definitions may be acceptable depending on their intended use, as well as the nature and scope of the responsibilities of the person who is defining them (Donabedian 1988). In the same wave length even JCAHO (1971) has stated that dimensions of health care performance especially those definable, measurable and actionable are attributes of the systems related to their functioning to improve health.

Later on Lalonde (1974) defined health care as the combined functioning of public health and personal medical services. A health care system therefore as per him is a set of activities and actors whose 
principal goal is to improve health through the provision of public and personal medical services. According to IOM (1990), quality of care can be defined as the degree to which health service for individuals and populations increase the likelihood of desired health outcomes, and are consistent with current professional knowledge. Hereby this definition encompasses a wide range of elements of care with reference to health services, identifies both individuals and populations as targets for quality assurance efforts, recognizes the importance of outcomes without specifying for whom allowing the possibility of differing perspectives on which values of quality are most important and also highlights the importance of individuals preferences and values and implies that the patients have been taken into account in health care decision- and policy-making.

Even Arah (2003) thought that health care systems have made various efforts to manage their problems. The latest of the efforts has been the deployment of performance, measurement, monitoring and improvement initiatives (Ibrahim 2001).

Department of health UK (1997) describes in a very original way quality of care by doing the right things to the right people at the right time and doing things right first time, while the EC (1998) state that quality of care is the degree to which the treatment dispensed increases the patient's chances of achieving the desired results and diminishes the chances of undesirable results, having regard to the current state of knowledge.

Furthermore as per latest developments CMS (2014) defines quality measures are tools that help measure or quantify health care processes, outcomes, patient perceptions, and organizational structure and/or systems that are associated with the ability to provide high-quality on health care, and/or that relate to one or more quality goals for health care, where the "goals" include effectiveness, safety, and efficiency, patient-centered, equitable and timely care.

\section{Identifications of indicators}

Qualities indicators are tools designed to measure quality of care and thus help enhance quality, by identifying areas needing improvements (Ingleton. et al 1999 and Cambell et al. 2003). Criteria for indicator selection depends on (i) the importance of what is being measured in terms of the impact on health status and health costs, the policy relevance and the susceptibility of the problem to intervention, (ii) the scientific soundness of the measure in terms of its validity, reliability and the explicitness of the evidence base and also (iii) the feasibility and cost of obtaining international data for the measure.

While Leatherman (2001) declared that indicators are necessary to measure performance, dividing them in four basic functions: facilitating accountability, monitoring health care systems and services as a regulatory responsibility, modifying the behavior of professionals and organizations at both macro and micro level, and forming policy initiatives.

Even Kahn (2002) and Lorenz (2006) have conducted extensive reviews on quality of care measurement using a number of considerations in developing quality indicators including acceptability, feasibility, validity and reliability. Similarly Arah (2005) in his efforts to measure performance in health care used 18 health care performance indicators, 6 of them was health indicators, 12 were non-medical determinant of health, and he included also 16 other indicators of community and health systems characteristics as independent variables for his analyses. The indicators he used to measure health care quality were: acceptability, accessibility, appropriateness, effectiveness and safety.

However one widely accepted and useful method for categorizing indicators of health care quality is the approach first conceptualized by Donabedian $(1980,2003)$ that describes indicators as being structure, process, or outcome in nature. These dimensions are also used to assess quality of care in a certain country.

- $\quad$ Structure indicators represent indicators of the characteristics of or inputs to health care. They may represent necessary conditions for the delivery of a given quality of health care but they are not sufficient. Their presence does not ensure that appropriate processes are carried out or that satisfactory outcomes are achieved by the health system.

- Process indicators represent measures of the delivery of appropriate health care to the relevant population at risk were appropriateness should be based on clinical evidence of the effectiveness of the process concerned and "consistent with current professional knowledge" of 
concern with process indicators is the degree to which these measures are related to clinically desirable outcomes (IOM, 2001). These are some concerns that process indicators are more vulnerable to gaming than outcome or structure measures. However, process measures represent the closest approximation of actual Health care offered and are the most clinically specific of the three types of indicators (OCDE, 2006).

- Outcomes indicators seek to represent measures of health improvements attributable to medical care. The main challenge to outcome indicators is that they may be influenced by other factors but quality of care, like age, severity of illness and socioeconomic status. For that is important to be sufficient evidence that quality of care makes an independent contribution to the outcome, and the factors that influence the outcomes should be appropriately accounted for by risk adjustment (OECD, 2006).

As different authors and responsible institutions refers to different dimension, in the table below is given a short summary of most commonly used and less used dimensions.

Table 1: Dimensions of quality care

\begin{tabular}{|c|c|}
\hline Most commonly used dimensions & Less commonly used dimensions \\
\hline $\begin{array}{l}\text { Effectiveness: the degree of achieving } \\
\text { desirable outcomes, given the correct } \\
\text { provision of evidence-based healthcare } \\
\text { services only to those who could benefit or } \\
\text { the degree to which processes result in } \\
\text { desired outcomes, free from errors. }\end{array}$ & $\begin{array}{l}\text { Acceptability: refer to conformity to the } \\
\text { realistic wishes, desires and expectations of } \\
\text { healthcare users and their families. Since a } \\
\text { person's healthcare experiences have a } \\
\text { powerful effect on their future utilization of } \\
\text { and response to healthcare. }\end{array}$ \\
\hline $\begin{array}{l}\text { Safety: the degrees to which health care } \\
\text { processes avoid, prevent, and ameliorate } \\
\text { adverse outcomes or injuries that stem } \\
\text { from the processes of health care itself, } \\
\text { closely related to effectiveness, although } \\
\text { distinct from it in its emphasis on the } \\
\text { prevention of unintentional adverse events } \\
\text { for patients. }\end{array}$ & $\begin{array}{l}\text { Appropriateness: is the degree to which } \\
\text { provided healthcare is relevant to the } \\
\text { clinical needs, given the current best } \\
\text { evidence. This dimension is most often } \\
\text { presented as part of effectiveness. }\end{array}$ \\
\hline $\begin{array}{l}\text { Responsiveness (patient centeredness): } \\
\text { the degree to which a system actually } \\
\text { functions by placing the patient/user at the } \\
\text { center of its delivery of healthcare and is } \\
\text { often assessed in terms of patient's } \\
\text { experience of their health care and } \\
\text { understanding that should characterize the } \\
\text { clinician-patient relationship. }\end{array}$ & $\begin{array}{l}\text { Competence: the degree to which health } \\
\text { system personnel have the training and } \\
\text { abilities to assess, treat and communicate } \\
\text { with their clients. There are many potential } \\
\text { aspects of competence including technical } \\
\text { competence as well as cultural } \\
\text { competence. This dimension, in terms of its } \\
\text { assessment can be included in } \\
\text { effectiveness. }\end{array}$ \\
\hline $\begin{array}{l}\text { Accessibility: the ease with which health } \\
\text { services are reached. Access can be } \\
\text { physical, financial or psychological, and } \\
\text { requires that health services are a priori } \\
\text { available. }\end{array}$ & $\begin{array}{l}\text { Continuity the extent to which healthcare } \\
\text { for specified users, over time, is } \\
\text { coordinated across providers and } \\
\text { institutions. }\end{array}$ \\
\hline $\begin{array}{l}\text { Equity: defines the extent to which a } \\
\text { system deals fairly with all concerned by } \\
\text { dealing with the distribution of healthcare } \\
\text { and its benefits among people. }\end{array}$ & $\begin{array}{l}\text { Timeliness: the degree to which patients } \\
\text { are able to obtain care promptly It includes } \\
\text { both timely access to care) and } \\
\text { coordination of care (once under care, the } \\
\text { system facilitates moving people across } \\
\text { providers and through the stages of care). }\end{array}$ \\
\hline
\end{tabular}


Data sources: Aday and Anderson, 1975; Shortell, 1976; WHO, 2000; Juran and Godfrey, 2000; National Patient Safety Foundation, 2000; IOM, 2001; Arah, et al. 2003; AHRQ, 2004; Donabedian, 2003

\section{Health care indicators in Albania}

The Albanian health sector suffers from inefficiencies and inequities. Out-of-pocket payments of patient's accounts for more than half of total expenditures spent on health. With only half of the poor covered by social health insurance, increased health spending has pushed more households into poverty. Unofficial payments remain common, particularly in public hospitals. Additionally key health system performance indicators in Albania are mixed, while health outcomes are relatively strong by regional standards, quality of care is a significant concern (WB, 2015).

In this perspective the evaluation of health performance which is closely linked to statistical indicators as part of the overall assessment of the health care system in Albania with the final aim to further consolidations and improvements of services offered is essential.

Despite the problems the sector is suffering, main indicators used show a consistent trend of improvement both for the primary health care and hospital services. This is in consistency with the objective of the Ministry of Health to ensure and continuously improve health care for its society, where special attention is given to services' access, quality, financial sustainability and efficiency alongside with enhanced service providers motivations considered as the main indicators that determine the level of service. However in Albania all health institutions when referring to the indicators that help to assess quality care (Nuri et.al, 2002; MH, 2009, 2010) and performance are speaking of longevity indicator, hospital morbidity, and chronic disease coefficient, infant mortality number, vaccination coverage, mental health indicators, infective disease distribution, cardiovascular diseases etc. The list of these indicators has been improved and expanded through years, but still is not the same that is adopted by EU, where Albania adhere to join. Chikovani (2008) in his studies argued that this list does not cover all categories necessary for planning, system performance evaluation, and health status measurement. Consequently the weakest point in relation to the indicators is their lack of selection methodology to ensure that the indicators are responsive to explicit criteria including usefulness, scientific soundness, reliability, representativeness, feasibility and accessibility. For a better health care assessment is important to evaluate all indicators used against scientific soundness including validly, reliability, specificity, sensitivity and usefulness. Even though these indicators can be considered as "tentative outcome indicators" as they are far from indicators adopted worldwide their use has been a remarkable progress evidenced in many reports in Albania as a good start to measure health sector performance at very first steps.

\section{Conclusions \& Recommendations}

Health presents a challenge for all nations and effective public health systems are crucial for providing care for the sick, and for instituting measures that promote wellness and prevent disease. Increasing awareness of variations in the quality of health care across geographic areas has helped boost a quality improvement from which to promote greater understanding of promising strategies for meeting and raising benchmark standards of care. It is also important to recognize that the definitions of quality of care are constantly evolving. Initially, the definition and assessment of quality was within the purview of health professionals and health service researchers. However, there is a growing recognition that the preferences and views of patients, the public and other key players are also relevant (LegidoQuigley et.al, 2008). Many countries has approved and implemented different indicators to properly assess health quality services starting from structure, process, or outcome nature, while in Albania the performance indicators are somehow mixed to missing of proper dimensions of quality care indicators.

Therefore the policymakers should be more attentive when it comes to prepare strategies to include the proper indicators that would support stable improvements of health sector in Albania that also will improve citizen's confidence that they have sufficient information available on the safety of health systems. 


\section{References}

1. Chikovani I, (2008),"Assesment of the health information system in Albania", Curatio International Foundation

2. Donabedian, A (1980). Explorations in quality assessment and monitoring. The definition of quality and approaches to its assessment. Ann Arbor, MI, Health Administration Press.

3. Donabedian, A (1988). The quality of care: How can it be assessed? Journal of the American Medical Association, 260:1743-1748

4. Helena Legido-Quigley H, McKee M, Nolte E and Glinos I, (2008), Assuring the quality of health care in the European Union", World Health Organization, Observatory Studies Series No 12

5. INSTAT, (2015), Methodology on Health, Social Insurance and Social Protection

6. IOM (2001). Crossing the quality chasm: A new health system for the 21 st century. Washington, DC, National Academy Press.

7. Ministria e Shendetesise, (2010), "Situata Shendetesore dhe Kujdesi Shendetesor, Arritjet dhe Drejtimet per te ardhmen",

8. Ministry of Health, (2009, April), "Heatlth in Albania and National background Report"

9. Nuri B and Tragakes E, (2002)" Health Care Systems in Transition”, EUR/02/5037245 (ALB) 2002

10. WB Albania, (2015), "World Bank to help improve quality, access, and efficiency of Albania's health care system", Press Release

11. Jeremy Hurst and Melissa Jee-Hughes, (2001), Performance measurement and performance management in OECD health systems .

12. Arah OA, Klazinga NS, Delnoij DMJ, ten Asbroek AHA, Custers T: (2003), Conceptual frameworks for health systems performance: a quest for effectiveness, quality and improvement. International Journal for Quality in Health Care, 15: 377-398.

13. Arah, O, Westert GP, Hurst J, Klazinga, NS. (2005), A Conceptual Framework for the OECD Health Care Quality Indicators. International Journal for Quality in Health Care.

14. Canadian Institute for Health Information (2004), Health Indicators. www.cihi.ca

15. Donabedian A (2003): An Introduction to Quality Assurance in Health Care. Oxford: Oxford University Press;.

16. Ibrahim JE (2001): Performance indicators from all perspectives. International Journal for Quality in Health Care.

17. Leatherman S, Sutherland K (2004): Quality of care in the NHS of England. British Medical Journal,

18. Lalonde M (1974): A New Perspective on the Health of Canadians. Ottawa: Office of the Canadian Minister of National Health and Welfare;

19. Smith PC, (2002): Measuring up. Improving health system performance in OECD countries. Paris: Organisation for Economic Cooperation and Development;

20. Smith PC: (2002) Measuring health system performance. European Journal of Health Economics

21. Murray CJ, Evans DB, (2003).: Health System Performance Assessment: Debates, Methods, and Empiricism. Geneva: World Health Organization.

22. Ingleton C (1999) The views of patients and carers on one palliative care service. International Journal of Palliative Nursing 5.

23. Kahn K, Malin J, Adams J, et al. (2002) Developing a reliable, valid, and feasible plan for quality-of-care measurement for cancer: how should we measure?

24. Lorenz K, Lynn K, Dy S, et al (2006). Southern California evidence-based practice center under Contract .Agency for Healthcare Research and Quality.

25. OCDE (2006), Health Care Quality Indicators Project Conceptual Framework Paper, OECD Health Working Papers. 